\title{
Candida albicans MORPHOTYPES FROM ORAL CAVITY IN SEVERAL FAMILIES
}

\author{
( Morfotipos de Candida albicans de la cavidad oral \\ en varias familias)
}

\begin{abstract}
Candido, R.C. ${ }^{2}$, Azevedo, R.V.P. ${ }^{2}$, Ito,I.Y. ${ }^{2}$, Fischman, O. ${ }^{3}$ \& Zaror,L. ${ }^{4}$
'Discipline of Clinical Mycology; 'Disciplinc of Microbiology.

Faculy of Phamacculical Scicnces of Ribcrão Preto.

U.S.P, Avenida do Caré s/N', 14040-903, Riberão Preto. S.P., Brasil.

Disciplima Biologia Cclular, UNIFESP, São Paulo, Brasil.

"Microbiologia Clinica, Faculad de Medicina, Universidad Austral de Chile.
\end{abstract}

P.O. Bor 567, Valdivia. Chilc.

Pahabras Clave: Camdida abicams, Cambitla spp., cavidad bucal, morfolipos, prótesis dentaria

Key words: Camdida albicans, Candida spp. oral cavity, morphotypes, denture plaque.

\section{SUMMARY}

A tomal of 108 individuals belonging w 22 fomilies consisfing of 3 to s members ench were studicdin onder to detect Camblata abicans morphorpess. leavis were isolated from the oral covity of at least one individieal per fomily, with or withont teeth.

Following Phongpaichit ef al rechinque, identical or differen momphonyess were detected in 7 fomilies. In

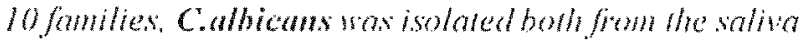
and the removoble denthe of the wane individual. It discontinums, fringe, considered to be a probable witi-

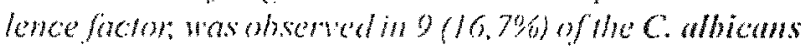
strains, from people having the complete sot of teeth, in the saliva of the former and of thowe using demure. A

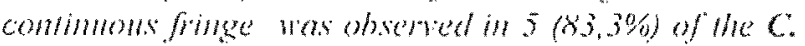

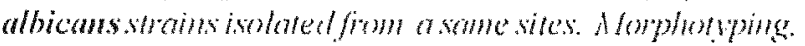
a simple and easily executed method which is usefill to detect cross-infection, mav serve as a "rish imblicator" for the accurence of condidosis:

C.abicams was the prevalent species $(96,490)$ detected in al teast 2 members from $1+$ fomilies.

\section{INTRODUCTION}

The presence of yeast in the luman oral cavity usually causes few complictions. The infection originated br these microorganisms may be fully asymptomatic allhongh lesions of the onal mucosa are clearly visible during clinical examination(1). The possible role of yeasts in the derelopment of oral cancer and in infections by microorganisms rectucres carcful antention(2). Pattents under treatment with

\section{RESUMEN}

Se estuliaron los personas provententes de 22 fomilias commuestas de 3 a 8 micmbros cala wha, para la bistateda de morfotipos de Candida allicans de la casialat bucal con o win piczas dentarias.

Por la ternica te Phongpaichit el al, morfotipos idénicos o diferentes fiteron tetectados en 7 grapos fomiliares. In 10 fomilias, Calbicans fue aistada te ta salivay de potosis dentarias remowibles de an mismo individuro.

La franja discontinua, considerada como prohable imdicator de virulencia fine defectade on $9(16.7 \%)$ de las cepas de C. abicans de persomas con dentición com-

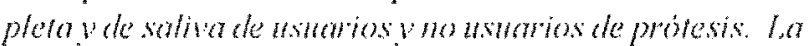
franja conima fine verificado en 5 (8,3,3\%) de las cepas

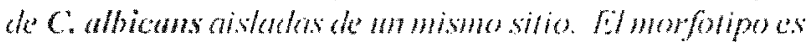
simple, facil de cjecutar, puede servir para detectar infeccion crazado y combo an posible indicator te riesge de candidosis.

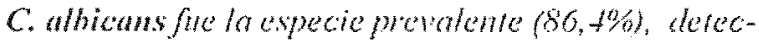

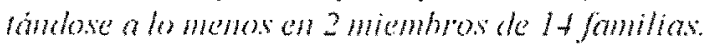

cylostatic drugs and radiotherapy are particularly vuhenble to yeasl infections(3.4). Oher local or systemalic predisposing factors such as decreased salivary flow. poor oral lygicne. tratment with corticostcroids, and immunologic deficiency may contribute to the transformation of these microorgmismis, usually considered to be commensill inlo diseise causing agenis(5.6).

It has been docmmented that the frequency of isolation and concentation of yeasts in the mouth increases among 
individuals wearing partial or full denture and that this increasc is associated with the appearance of erythematous areas in the oral mucosa $(7,8)$. According to Lal et al.(9), stomatitis caused by denture, may scric as a model system for the study of infectious processes causcd by Camlida albicans and olher Candida specics in the oral cavity.

Over the last few years several studies have been conducted to characterize yeasts not only in terms of species for taxonomic purposes, but also in terms of pathogenicity and mainly for cpidcmiological studics. In the case of the phenomenon of morphologic variation of C.albicans, the technique called morphotyping is used $(11,13)$. Borronco e't al.(10) morphotsped Calbicans isolated from the oral cavity and noted that differen morpholypes were isolated from smokers' denture and without crythematous candidosis, and from smoking and non-smoking denture wearers who presented the discase; a single ype was isolnted from non-smokers with a hallty oral mucosal wearing no dentures.

Considering that oral infection with ycast may occur by direct or indirecl contacl between infected and non infected individuals and that dentures may serve as reservoirs of these microorganisms.

In the present study we isolated and identificd ycasts from salive and denture plaque samples oblained from persons belonging to the various family groups 10 decrmined the intrafamily similarity of $C$. alhicans strains by the morplotyping technique.

\section{MATERIAL AND METHODS}

We scleded 22 familics residing in lie town of Ribcröo Prelo. S.P. Brail of differen sociocconomic lerels and consisting of at least three menbers. including lic parents, one of whom had to be a wearer of a denture.

Colonics wilh reast chmacteristics isolated in SB20 culure modium modificd (14) from siliva and denture plaque samples were growth on agar Saboumud (Sibound Dextrose Agar-Difco) supplenented with $50 \mathrm{mg} / \mathrm{L}$ chlom ramphenicol mainatined at room tempcralture. Aficr development. the ycast colonies were plated on agar Sibouraud for mantcounce.

Yeast were identificd by classical mehods $(15)$ using the following Iesis: microculture on Cormeal agar. germ tube in human serum. fementation/assimilation of different carbolydrates and nitrogen compounds.

Morphotyping was carried ou by the technigue of Phongpaichit et al.(13). Calbicams suspensions in stcrilized distilled water containing approximately $1.0 \times 10^{7} \mathrm{cell} / \mathrm{mL}$. were swabbed on plates containing Mall Extact Agar (Oroid) and incubalcd at $30 \mathrm{~m} \mathrm{C}$ for 10 days. The results were read in terms of morphological aspects related to colony fringe and surface. recorded by means of 4 digit codes according to the method of Hunter et al (12) for later intcrpretation.

\section{RESULTS}

The 22 families selected consisted of 3108 individuals each (mean=3), for a total of 108 ; 25 of them wearing full denturcs and 83 with matural tcelh. Thus. the sampling consisted of 133 matcrials, i.c., 108 saliva samples (83 from dentate individuals, 25 from denture wearers and 25 from the denture plaque).

Yeasis were detceted in the oral cavity of at least one individual per family for a total of $61(56.9 \%)$ and the following specics were identificd: Calbicans, C.tropicalis, C.partipsilossis, C.fomatu, C.guillermondi, Candida spp. and Trichosporon spp. (Table 1).

TABLE 1 .

Yeasts species isolated from the oral cavity of the various family groups

\begin{tabular}{|c|c|c|c|c|}
\hline \multirow[t]{2}{*}{ Specics } & \multicolumn{2}{|c|}{$\begin{array}{c}\text { Familics } \\
\text { (22) }\end{array}$} & \multicolumn{2}{|c|}{$\begin{array}{l}\text { Individuals } \\
\text { (108) }\end{array}$} \\
\hline & $N^{\circ}$ & $\%$ & $N^{\prime \prime}$ & $\%$ \\
\hline Camelida abicans & (1) & 86.4 & 43 & 39,8 \\
\hline Candida tropicalis & 7 & 31.8 & 9 & 8.3 \\
\hline Candida parapsilosis & 6 & 27.3 & 8 & 7.4 \\
\hline Candida fomatu & 1 & 4.5 & 1 & 0.9 \\
\hline Condida guilliermondi & 1 & +.5 & 1 & 0.9 \\
\hline Candida spp. & 3 & 136 & 3 & 2.8 \\
\hline Trichosporon spp. & 1 & 4.5 & 1 & 0.9 \\
\hline
\end{tabular}

Twenty of the 25 full denture wearers $(80 \%)$ arried the ycast. 15 of them presenting it boll in salisa and in denture plaque. 3 only in siliva and 2 only in denture plaque. It should be cmplasized that 15 of the 20 denture wearers weremonocolonized and 5 multicolonized.

Yeisls were isolalcd from +1 saliva samples from nondenture warers (49.4\%), all of them monocolonized.

C.abicums. the provalen species. Was isolated from (9) fmilies for a tom of 54 stmins from saliva and/or dentures. Or hese 19 familics, $14(73.7 \%)$ had at least 2 members colonized by this species. In 10 fanilies $(57.9 \%$. C. albicans was also isolated from the saliva and denture plaque of the sime individual (Table 2).

Typing of the $5+$ C.abbicans samples resulted in 20 different morphotypes. the most frequent being number 5330.5340 and 5240 (Table 3). Table 2, shows that in 7 fumilics (N'3, 5.11, 15, 16, 17, 22), 2 individuals harbored $C$. abicams strains of the same morpholypes. Among the 
TABLE 2.

Morphotypes of $5+$ Candida albicans strains isolated from 43 individuals belonging to 19 families

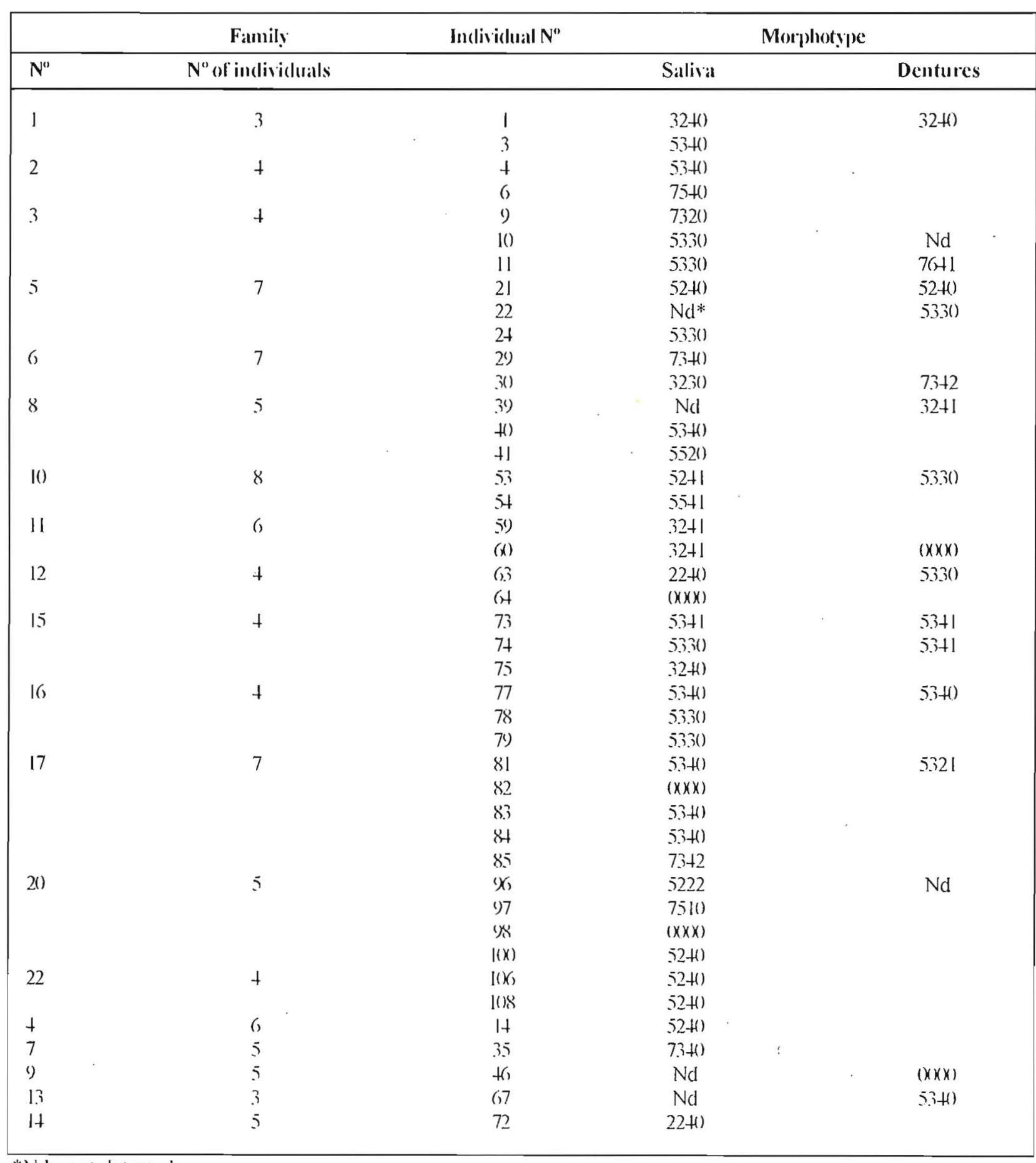

*Nd: not delceicd

denture wearers. + individuals (N"1.21.73. 77) caltricd strains of the sime lype bolth in salina and on clentures (Tablelc 2).

Colonics with discontinuous fringes were observed in
9) Strains $(16.7 \%)$ and colonics with continuous fringes were observed in $+5,(8,3.3 \%)$. Or (he') strains with cliscontinuous fringes. $2 / 15(13.3 \%(1)$ were from denlure plactuc. $+/ 1+(28.6 \%)$ from the siliva of denture wearers and $3 / 25(12.0 \%)$ from the salliva of non-denture wearers (Table 3). 
TABLE 3.

Morphotypes of $5 t$ C.albicans strains, isolated from dentures, saliva of denture wearers and from the saliva of no denture wearers

\begin{tabular}{|c|c|c|c|c|}
\hline & \multicolumn{2}{|c|}{$\begin{array}{c}\text { Denture } \\
\text { wearers }(20)\end{array}$} & \multicolumn{2}{|c|}{ No-denture } \\
\hline $\begin{array}{l}\text { Morphotype } \\
\text { (20) }\end{array}$ & $\begin{array}{c}\text { Denture } \\
\text { (15) }\end{array}$ & $\begin{array}{l}\text { Saliva } \\
\text { (14) }\end{array}$ & $\begin{array}{c}\text { Saliva } \\
.(25)\end{array}$ & Total \\
\hline$(x)(x)$ & 2 & () & 3 & 5 \\
\hline $22+0$ & 0 & 1 & 1 & 2 \\
\hline 3230 & 0 & 1 & .0 & 1 \\
\hline $32+0$ & 1 & 1 & 1 & 3 \\
\hline $32+1$ & 1 & 1 & 1 & 3 \\
\hline 5222 & () & 1 & 0 & 1 \\
\hline $52+0$ & 1 & 2 & 3 & 6 \\
\hline $52+1$ & () & 1 & 0. & 1 \\
\hline 5321 & 1 & () & () & () \\
\hline 5330 & 3 & 3 & 3 & 9) \\
\hline $53+1)$ & 2 & 2 & 5 & 9) \\
\hline $53+1$ & 2 & 1 & () & 3 \\
\hline 5520 & () & () & I & I \\
\hline 5.41 & () & 0 & I & I \\
\hline 7320 & 0 & () & 1 & 1 \\
\hline $73+40$ & () & () & 2 & 2 \\
\hline $73+2$ & 1 & () & 1 & 2 \\
\hline 7510 & () & () & $\because 1$ & l \\
\hline 7540 & () & () & 1 & I \\
\hline $76+1$ & I & () & 0. & I \\
\hline
\end{tabular}

\section{DISCUSSION}

Ycasts, and C.albicans in particular. are integrating microorganisms of the normal microbiola of the oral cavity. which is altered in palicnts who carrier denturcs. causing the so-called denture stomattilis (DS). In a study of ycastlike fungi among college students fiom Porto Alcgre, Braxil. Santos(16). found ycissts of the genus Candide in $40.7 \%$ cren though they were adults wilh higher education. dental students with ample information about oral hygicne.

In a study of ycast distribution and concentration among 5) paticnts with DS. Darcuport(17) noted that t9) $(98 \%)$ Salival sampies werc positive comparce $10.30(6)(60 \%)$ from subjects without the discasc. C.albicuns was isolated from $7(0 \%)$ or the pat icnls with slomal itis and from $20 \%$ of the controls. and other species were detected in $1+\%$ and $16 \%$ of paticnts with and without DS. respectively. Narhi et al.(18), reported that hight ycast counts in salliva werc associatcd with Icsions of the oral mucosil but not with individual complaints of buccal symploms. They observed that $3.3 \%$ of dentale inclividuals. $25 \%$ of partial denture carricrs and $20 \%$ of full denturc carriers were also free of this microorganism.

Our results about the incidence of yeasts in the oral cavity of adults $(56.9 \%)$ agrec with data reported by Darenport( 17), who isolated these microorganisms from $60 \%$ of subjects with no stomatitis. It is more common to find ycasts among denture wearers $(80.0 \%)$ than in individuals with natural tecth $(49.4 \%)$ agrees with data reportcd by Parvincn(7) in Finland.

The prevalent species, C.albicans, was isolated from $39.8 \%$ of the individuals analyzed in the present study. a lower frequency than that reported by Davenport(17) in this study of saliva from individuals with slomatitis $(70 \%)$. However, this frequency was higher than that reported by this aulhor for indivicluals wilhout the discase and also higher than that reported by Arcndorl \& Walker(19), who isolated this species from 2\%.6\% of the saliva samples sludicd.

The litcrature conlains many' descriptions of icchniques for the differentialtion of C.albicans strains, such as scrotrping. resislogram, susceptibility to killer toxins, crisme production and different techniques at the molccular level (20),21,22,23).

In the present screening of C.albicans strains isolaled from the members of a family group by the morpholyping technic|uc. we noted that 7 of the $1+$ families $(50 \%)$ with at least wo individuals colonized by this species, presented individuals with the sime morphotype in the oral cavity. and in 3 fimily groups the morphotypes of the strains of certain individuals were characierized by the fact that they' only differed in one digil (Table 2). This facl. by itscle, is nol indicative of intral fantily transmission, howercr. the occurrence or these pairings in a restricled cluster such as the lamily: allows us to infer that some C.albicans strains may have becn transmitted in an int rafamily manner. The obscrvation that in $4(36.4 \%)$ of the to families in which $C$. albicans was isolated from the silliva and/or from the denture of the same individual, the morphotype was idculticil in the two simnples (Table 2). reflects the possibility that the microorganisms were from a single source. the clenture. which is considered to be a yeast reservoir in the oral calvily. The detection of difrerent morphotspes in stritus isolated from the saliva and the dentures of the same individuals was possibly related to the fact that difrerent sources cxisted in the oral cavily. such as lesions of the oral mucosa. or that the same inclividual possibly carricel more than one morpholype in the same sitc.

Hunter e' al. (12). using morphotyping for differentialtion of C'albicanss strilins. obscrved a malrked associaltion between the presence of discontinuous fringes challacierized by the ["t. digit (N"1.2 and 3) of the typing sy'slem in colonies of these species isolated from samples obtained from patients who suffered al fatal infection. According 10 
these investigniors, the disconimous fringe may serve as an indicator of C.abicans virulence.

Ourdata demonstrate (hat most of the status $(45 ; 83.3 \%)$ had continuous fringes (Table 3 ). which is not surprising if we consider that all stains were from the oral cavily of apparcnly heallyy individuls. As to the $9(16.7 \%)$ stains wilh discontimous fringes, those considered virulent $(3$; $12.0 \%$ were from the saliva of 25 individuls without dentures, while the other 6 strains were isolated from 4 (20\%) or the 20 denture carricrs 2 or them from the dentures and 4 from saliva. These data indicate that $12 \%$ of the individuns with normal icell and $20 \%$ of the denture carricrs are susceplible to the disease (candidosis) if no preventive measures are provided for.

Morpholyping: a simple standard method that permits the individulization of isolated strains, can be applied to complenent olher phenolypic biotyping tcohniques such as lhose based on fungal molecular biology.

Thus, morphotyping may serve as a "risk indicator" for the acquisition of candidosis, especially among full denture carticrs.

\section{REFERENCES}

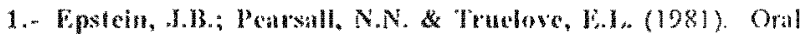
candidiats: Eneels of mollugal therapy upon chion signs and symptoms, silivary antowy, and mucosal adherence of Comdida albiens. Ond Sury. Ond Med. Onal Piathol. $51: 32-36$

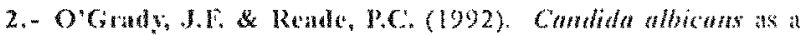
promoter of oral mucosal nicophasia. Curcimggenesis. 13:783-786

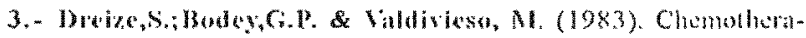

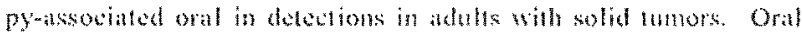
Surg. Oral Med. lathol. 55:113-120

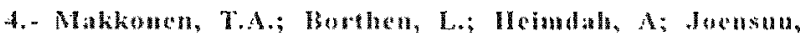
H.II.; Lehfonen, O.P'; Nord, C.B. (1989). Oropharyngeal colonisation with hungi and gram negalive tods in paticn trealed with radiolhorapy of the bead and wok. Br. J. Oral Maxillo Fac, Surg. 27:334-3.40

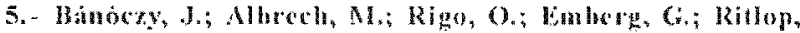
13. (1987). Saliary secretion rate pil. lactohatili and yeakt counts in diabetie wemen. Leta Diabetol Lat. 24:223-228

6.- Stud, R.J. \& Conte, N.J. (1989). Adverse ellects of whiced corricosstoroids. 13r. Med. I. $298: 403.404$

7.- Manden, I. (1084). Stimulated salivary how rat, pll and laclobillus and yeast coneentrations in persuns with tilleren lypes of dentations. Scand I. Dem. Res, 22:412-418

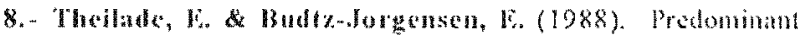
cultivable mitoflora of platue on removable dentuss in putionts

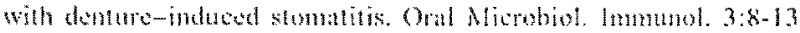

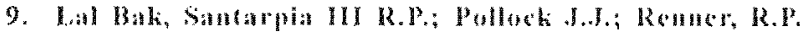
(1992). Assusmont of antimerohial reament of donture stomatios using an in tho replica modes system: Theriprethe elleaty of an oral rins. I. Prost. Dem. 67:72-77

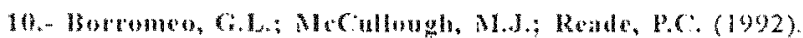
Quantilication and morphotyping of Camble abicans from heathy

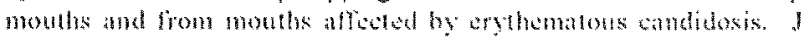
Med. Vu. Myeol. 30:477-480

11.- Camdius, R.C. (1991). Candida abienns: Marcadores

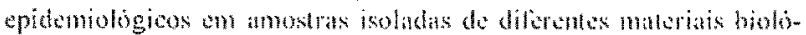

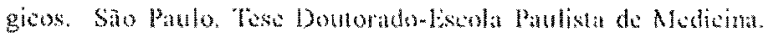

(1989). Norphotype markers of virulenes in human candida! infetions. J. Med. Mierohol. 28:85-91

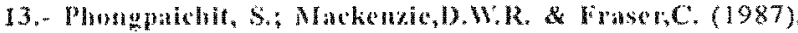

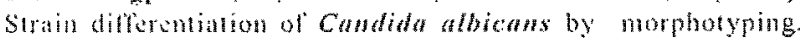
Epidem. Intect. $99: 421-428$

14.- AHescto, R.V.R. (1988), O emprego da bacieriotipagem (mutacinotipagem) no rastramento epidemóógico de estroptococos do "grupo mutans". Tese de Dowtorado -Instituto de Ciencins Biomedicas da Unibersidude de Săo Paulo.

15.- Vun Der. Walt, N.13. \& Yarow, D. (1284). Nethods for the isolation, mantenance, chussification and identilication of yeast. In: N.I.W. Kreger-san Rij. (Bd.). The Yeasts: a taxonomio study. Elsevier, Amsterdam. pp. $45-104$

16.- Samtos J.0.\$. (1261). Presenģ de Candida abicams na saliva. Rev. Gaucha Odon. 9:80-82

17.- Daremport, I.C. (1970), The oral distribution of Candida in demure stomatitis, Brit. Dem. $1.129: 151-156$

18.- Ninthi, T.; Anamu, A. Meurman, J.11. (1993). Salivary yests saliva, and orat mucosa in the dderly. J. Dem. Res $72: 1009$. 1014

19.- Aredorf, T.M. \& Walken,D.M. (1980). The prevalence and intra-oral distnhution of Condida abicans in man, Arche. Oral. Biol. $25 \div 1 \cdot 10$

20.- IIowedl,S.A. \& Noble,W.C. (190m).Typing tools for the insestigation of epidemic hungal infection. Epitemiol. Infeat. 105: $1 \times 9$

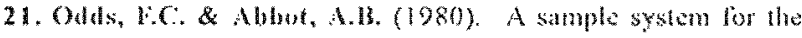
presumbive identification of Camalida albieans and dimerrentiation of strains within the spetes. Sabouratita $18: 301-317$

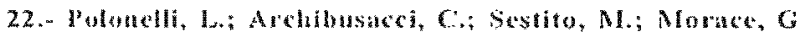
(1983). Killer sysem a simple method for difrerentiang Candida albicans strains. J. Cfin. Nicrohiol. 17:774-780

23.- Shenew, S. Se Stwens, D.A. (1989). Application of DNA yping maluods to eputemiology and laxommy of Candida species. f. Clin. Mierobiol. 25:675-679

12.- IUnEe, P.R, Mraser, C.M.M. \& Mackende, D.W.R. 